\title{
Borrelia Burgdorferi IgA Antibody Measurement
}

National Cancer Institute

\section{Source}

National Cancer Institute. Borrelia Burgdorferi IgA Antibody Measurement. NCI

Thesaurus. Code C122099.

The determination of the amount of Borrelia burgdorferi IgA antibody present in a sample. 